\title{
THE DISCUSSION ON RELIGIOUS AND ETHNICAL DICTIONS OF ONLINE HEADLINES
}

\author{
(Kajian Diksi Berkaitan dengan Religi dan Etnis pada Judul Berita Utama Daring)
}

\author{
Irawan Syahdi \\ Balai Bahasa Provinsi Aceh \\ Jalan T. Panglima Nyak Makam No.21, Lampineung, Kec. Kuta Alam, \\ Kota Banda Aceh, Aceh 23125 \\ e-mail: Irawan_Syahdi@yahoo.com
}

Diterima 10 Agustus 2020

Direvisi 23 September 2020

Disetujui 26 September 2020

https:// doi.org/10.26499/und.v16i2.2737

\begin{abstract}
This study discusses the effects or impacts of using diction related to ethnicity and religion or belief found in several online headlines. The method in this study is a descriptive method with a qualitative form of research stated by Kaelan, and uses data analysis techniques suggested by Miles and Huberman. This discussion of diction uses the theory put forward by Gorys Keraf. Based on the results of data analysis, it is found that the use of diction related to a particular ethnicity or religion as a whole will give and trigger negative effects or impacts on the social community who read it, even though the news presented is based on actual facts.
\end{abstract}

Keywords: Headlines, diction, religious, ethnic

Abstrak. Penelitian ini mendiskusikan efek atau dampak pengunaan diksi yang berkaitan dengan suku dan keagamaan atau kepercayaaan yang ditemukan dalam beberapa judul berita utama daring. Metode dalam penelitian ini adalah metode deskriptif dengan bentuk penelitian bersifat kualitatif yang utarakan oleh Kaelan, dan menggunakan teknik analisis data yang disarankan oleh Miles and Huberman. Diskusi penggunaan diksi ini memanfaatkan teori yang dikemukakan oleh Gorys Keraf. Berdasarkan hasil analisis data ditemukan bahwa penggunaan diksi yang berkaitan dengan suku atau agama tertentu secara keseluruhan akan memberikan dan memicu efek atau dampak negatif bagi masyarakat sosial yang membacanya, walaupun berita yang disajikan berdasarkan fakta aktual.

Kata Kunci: Berita utama, diksi, religious, etnis

\section{INTRODUCTION}

Diction or also often called word choice is a very important factor in the writing process, especially the news. The selection of less proper or incorrect words can result in different meanings. Different in this case can be in the form of a misunderstanding by the reader regarding a writing, and then the actual message contained in the writing will certainly not be conveyed, as a result of unwise selection of the diction. Therefore the choice of a good word should contain or meet provisions such as 'proper', 'right', 'common', and 'wise'. The four factors are of course adjusted and considered based on social conditions when the writing or news will be released.

Keraf (2008, pp. 89--108) understanding the choice of words or diction is far broader than what is reflected by the relationship of those words. This term is not only used to express which words are used to express an idea or ideas, but also includes phraseology, style of language, and expressions. Then he also revealed that it is clear that someone who has broadly vocabulary and knows the exact limits of his understanding, will also express what he meant. 
The accuracy of the choice of words or diction does not only question the ability of a word to generate and arouse proper ideas in the imagination of the reader or listener, such as what the writer / speaker thinks or feels, but also used to express which words are appropriate and suitable to use to express the ideas, so that they still have a positive effect on society. Exactly based on the conditions of events that happen in a social society, and related to the disclosure of ideas carefully. While the truth means that it must be in accordance with the applicable rules of language. The prevalence means that the use of the word is really well known in general. Then, it is wise to choose words or diction so that they will not cause conflict or further worsen the conditions in a society. Perfect understanding of writing or news by using diction selection based on the above factors, so that it still maintains stability or conducive conditions in the community are the most important things to fulfill.

The definition of headline itself can be defined as text that shows the nature of the article below. The purpose of the headline itself is to quickly draw attention to the content (Wikipedia). So headlines may also be said to be the titles that are made specifically with the intention of making it more effective and directing readers interested in reading the articles or material presented by the titles.

Headlines in addition to having an understanding as the headline or essence of news, headlines are also considered to be the news that become main reportage, lie on the front page, and the headline is printed more greater than the framework of the story that will determine the interest of the readers to read or not (Itule \& Anderson, 2003, pp. 116)

The variations in the presentation of headlines are made as such that the readers are interested in the news. Thus, the headline also works to attract the readers to read, hear or watch it. In this case we recognize various forms of headlines based on the news interests, harmonious deck of the headlines, typography and placement of the news (in newspapers or magazines) (Itule \& Anderson, 2003, pp. 116).

So, News is a notification about facts or ideas within a certain period, which was chosen by the editor of a newspaper to broadcast, which can attract the attention of the reader because of its extraordinary, or because of its importance and the consequences it would cause, or because it includes human interest, emotions and tension (Assegaf, 1991, pp. 24).

For journalists, it will be very meaningful if the news he makes becomes a headline in the daily or newspaper where he works / serves. From here, the more often the news he made the headlines will make him more famous, etc. Then there are tricks or very accurate ways in making the news headlines, one of them is by using the right choice of words or dictions, which can attract people to read it. Diction is very decisive in attracting interest and curiosity of the prospective news reader to read the content or material presented by a journalist.

There are several language studies on social media, such as Indrwati studies the persuasive language of millennials in the 2019 presidential election on Twitter (2018)); and examines the types of persuasion sentences, through the elaboration likelihood model analysis on Facebook (2019). Lusita (2018) examines 
diction, figurative language, imagery, and the value of character education in Indra Tranggono's short stories of Women Edited by Waves of Works.

Discussing on the function of headlines in the news is surely quite interesting. Many people who may not be so aware that they can actually be interested in reading news because of being "provoked" from the headlines of the news. When defined, headlines are the initial part of the news. This might be a bit similar if we compare it to news title. But basically, the sentences in the headline are much clear and also able to provide a general picture of the news. It is different from the title, where the sentence is usually shorter and describes less details of the news.

Headlines basically are useful to be an introduction to the news. This section will probably determine whether someone will continue reading the contents of the news or not. This is also related to forming a mass communication function of the news. Because of the importance of the main purpose of this headline, it is not surprising if we have to know what is the basic function of this headline.

1. Introduction to the news

The first function of headline, as mentioned earlier, is an introduction to the news. The headline will be the first part that will lead the reader to what exactly will be discussed from the news. The ability to make a news introduction will certainly make it even better in making news.

2. Describe news summaries

A summary of the news can also be displayed in headlines. The nature of this summary is usually just a general description but has not reached the conclusion stage yet. Generally, this is used to make readers more interested in what will be discussed in the content. This constitutes to be the function of communication media from the news.

3. To Attract the reader's attention

The reader's attention can be drawn only by using interesting headlines. Sentences with "bombastic" words or dictions are usually used in order to make the reader's attention focused on the news that will be delivered. Generally, headlines with larger font sizes will be used as an introduction to the headlines of a rubric.

\section{To Make readers curious}

As explained that the function of describing news summaries, the nature of the headline will not conclude the contents of the news. In order for the news to be read to the end, usually headlines will only give statements that provoke the reader to proceed to the following paragraphs. At the end, the conclusions from the contents of the news will use the sentences that have already been mentioned so that the readers still have to read the contents in sequence.

5. News digest provider

Because of its non-concluding nature, the headline's function in the news itself also only provides the essence. The point of view of the headlines is generally neutral (as a matter of fact that's the way the news should be). However, the contents of the next paragraph can use certain people's arguments or points of view without removing the essence of the news. It depends on the types of news to be delivered.

6. Facilitate the grouping of news

The presence of headlines will also make it easier to group the news. In addition, it's concise and attentiongrabbing nature will also make it easier for readers to classify the type of news. 
This is one of the important factors that can be used to be an interesting and a unique technique for writing the news.

7. Provide an explanation

Headlines provide the essence of a story, so it's not surprising that later this section will also have a lot of specific explanations. The sentences used are usually using straightforward sentences (containing denotative meaning, instead of connotative). Readers don't want to read something figurative and think too much when reading a headline. A good news writing technique can make the news easy to understand.

8. Provide a stimulus to read the news

This is also a quite important function of headlines. Stimulus or reading stimulation can be formed from this headline. Surely this makes anyone more aware that the existence of headlines in a news cannot be underestimated. There is news value that can even appear merely from headlines.

Various functions of the headline are indeed interesting. Headline functions in the news can provide our convenience, especially when writing a good news that can attract attention.

\section{LITERATURE REVIEW}

According to Ambo (1988, pp. 101) diction or choice of words is the use of words correctly to represent the thoughts and feelings that want to be expressed in the pattern of a sentence. While another opinion expressed by Widyamartaya (1990, pp. 45 ) which explains that diction or choice of words is the ability of someone to distinguish precisely the nuances of meaning in accordance with the ideas to be conveyed, and these abilities should be adjusted to the situation and the value of senses that belong to a group of people and listeners or reader. Dictation or choice of words always contains the accuracy of the meaning and suitability of the situation and the value of senses of the reader or listener.

While Keraf (1996, pp. 24) revealed three main conclusions regarding dictions, among others, as follows.

a. The choice of words or diction includes understanding what words are used to convey ideas, how to form the groupings of the right words.

b. The choice of words or diction is the ability to precisely distinguish the nuances of the meaning of the ideas to be conveyed and the ability to find a suitable form for the situation and the perceived value of the community.

c. The right and appropriate choice of words is only possible by mastering a large number of vocabularies.

From several opinions mentioned above, it concluded that diction is the selection and the use of words by the author by considering aspects of the denotative and connotative meaning of words, because a word can cause various meanings.

2. The type of Dictions

The type of dictions according to Keraf, (1996, pp. 89--108) is as follows.

a. Denotation is a basic concept that is supported by a word (meaning refers to concepts, referents, or ideas). Denotation is also a dictionary or main definition of a word, as opposed to a connotation or meaning that has something to do with it. Denotation refers to the true meaning.

b. Conotation is a type of words that have additional meanings, imagination or certain sense of values. Connotation is impressions or associations, and is usually has emotional nature caused by a word beside the dictionary boundary or its 
main definition. The connotation refers to the special meaning or additional meaning.

c. Abstract words are words that have conceptual referents form, abstract words are difficult to describe because their references cannot be absorbed by the human senses. Abstract words refer to quality (heat, cold, good, bad), affinity (quantity, number, level), and thought (suspicion, determination, trust). Abstract words are often used to explain any technical and specific thoughts.

d. Concrete words are words that refer to something that can be seen or sensed directly by one or more senses. Concrete words refer to actual and specific items in experience. The concrete word is used to present live pictures in the mind of the reader that exceeds other words.

e. A general word is a word that has a wide scope, general words refer to many things, to the set, and to the whole. Examples of common words: animals, plants, criminals, vehicles.

f. Special words are words that refer to specific and concrete directives. Special words show special objects. Examples of special words: Yamaha, Nokia, older brother.

g. The scientific word is a word used by scholars, especially in scientific writings.

h. Popular words are words that are commonly used by all levels of society, whether by educated people or by ordinary people.

i. Jargon is technical or secret words in a particular field of science, in the fields of art, commerce, secret groups, or other special groups. j. Slang is informal non-standard words, arranged in a typical, powerful and humorous manner used in conversation; slangs also constitute to be high and pure words.

k. Foreign words are elements derived from foreign languages which are still retained in their original form because they have not been integrated with the original language.

1. The absorbed word is a word derives from a foreign language that has been adapted to the form or structure of the Indonesian language.

Mustakim (Mustakim, 1994, pp. $41)$ to distinguish between selecting words and word choices. Word selection is the process or action of choosing words that can express ideas correctly, while choice of words is the result of the process or the action.

Based on the above opinions, it can be concluded that diction is the choice of words and the proper use of words with ideas to represent the thoughts and feelings to be conveyed to others and expressed in a sentence pattern both verbally and writing to bring up the function or its own effect for the readers.

\section{METHODOLOGY}

This study uses a qualitative descriptive method that aims to describe the dictions naturally based on objective data collection techniques. According to Kaelan (Kaelan, 2012, pp. 5) qualitative research is research that emphasizes more in terms of quality naturally because it involves understanding, concepts, values and characteristics inherent in the object of research. Sources of data are taken from various headlines or titles, and several sentences contained 
in the contents of the news from the related headline or titles. While the data is in the form of words or dictions related to religion and ethnics.

And data analysis in this study uses the Milles et al., (1992, pp. 10) techniques, namely by:

1. Read the text as a whole then collect data that has already been marked by taking some notes. The data taken are choice of words or dictions used in headlines

2. The data in the form of simple words choice or diction that contain explicit or clear meaning will come for analysis

3. Drawing conclusions from data that has been analyzed.

This research also makes use of supporting information taken from various sources such as through internet browsing which is also used to further clarify the theory and the purpose of the analysis made for each topic so that the ideas that emerge from researchers will be stronger with these supporting ideas.

\section{RESULT AND DISCUSSION}

Meanwhile, the role of mass media is very important because mass media play an important role in various aspects.

One of the role of mass media is to be able to build influence through determining the context and construction of events using language. The language used by mass media represents certain social and political groups. Events that are deemed appropriate to be published will tend to be used in the community as a way to discuss groups or certain events.

Language and especially the choice of words used by the mass media are important because the mass media tells events, constructs the reality of these events, and becomes meaningful articles or discourses. In the process of reconstruction, language is the main instrument in telling the reality.

The mass media is also a part of the community that serves to disseminate information about many aspects of people's lives themselves by using language which incidentally is a cultural outcome of the community that will continue to grow. So, basically, mass media and language are a unit that can influence how a situation or condition of a society by providing information about an event, which then can also influence people's thinking patterns, even mentally influential.

In this case, the wisdom of mass media actors is very necessary in using language, especially in determining word choices when making news, so that it can help create conducive social conditions.

Let us briefly do a flashback of the events in the capital city of Jakarta relating to the case of blasphemy that happened to the former Governor of Jakarta Basuki Cahya Purnama or better known as Ahok. So many news with highly 'ambiguous' headlines about him and the case. The headlines both directly and indirectly has caused anxiety and influenced conducive conditions in the society at that time, especially Jakarta. Let's take a look at examples of the following news headlines or titles below:

1. "Jakarta's Christian governor Ahok found guilty in Islam blasphemy trial"

The above headline sources from http://www.abc.net.au/news/2017-05-09/jakartasoutgoing-governor-ahok-found-guilty-in-

blasphemy-trial/8509936.

For certain mass media, especially foreign mass media, of course the headline is considered to be an interesting thing for the public to read, and will become a "top headline" regardless of the possible impact on 
society. The headline will directly or indirectly affect community mentally where the case occurred. The choice of words for the headline above is clearly very unwise, contrasting the words Christian and Islam. This of course greatly affects the psychology of the two communities or followers of the two religions, and can cause hatred between the two.

This is where mass media with their dictions should play an active role in defusing and trying to maintain a conducive situation in society by making truly informative but elegant news, so that it can provide a sense of peace in the 'turmoil' by using the right and wise word choices, and not making them as a 'stove' for sensitive events like the headline above.

In this case, let us look at an example of the following news headline originating from https://www.theguardian.com/world/2017/m ay/09/jakarta-governor-ahok-found-guilty-ofblasphemy-jailed-for-two-years.

2. "Jakarta governor Ahok sentenced to two years in prison for blasphemy"

Here Ahok's status is to remain as a governor of Jakarta without having to adding the words 'Christianity' and 'Chinese'after his name, because who is considered guilty of blasphemy is only Ahok individually and have nothing to do with his religion or ethnicity. Here the readers' minds should be directed and brought to focuse only on Ahok's status as a governor of Jakarta, no more. The headline above uses neat and wise dictions.

The followings are two news headline relating to competition in the Jakarta gubernatorial election between Basuki Cahya Purnama and Anies Baswedan some time ago quoted from https://www.usatoday.com/story/news/world /2017/04/19/election-jakarta-indonesiagovernor-anies-baswedan/100646116/.

3. "Muslim voters oust Jakarta's Christian governor"

And the title quoted from https://www.theguardian.com/world/2017/ap r/19/divisive-campaign-for-jakarta-governorsees-muslim-candidate-elected).

4. "Muslim candidate beats Christian in divisive Jakarta governor vote"

Basuki Tjahaja Purnama concedes defeat to Anies Baswedan after campaign in which religious and ethnic tensions were key Jakarta's governor, Basuki Tjahaja Purnama, better known by his nickname Ahok, has conceded defeat to rival candidate Anies Baswedan in a runoff election after a polarising and fraught campaign that exposed religious and ethnic divisions in Indonesia's capital.

The two examples of news headlines above clearly use extremely unwise dictions or choice of words. In making headlines and their contents, it should avoid using dictions or choice of words that can inflame religious or ethnic issues.

They are the most straight provoking headlines by evidently putting two religious dictions 'Islam' and 'Christian' and crash the two to each other by using the word 'beat' and 'oust' as well to emphasize. This would create a jealousy among the losing followers and result in incondusive condition in society.

However, on the other way around, the lines of the two paragraphs of the second headline are wisely written, eventhough indeed there was religious and ethnic tensions colored the governor election of the moment, but since no sensitive religious and ethnic dictions here are used, it would not affect much the society and create a jealousy which 
could cause insecured situation in society.

Then let's compare with the two examples of the following news titles quoted from

http://www.globeasia.com/newsmakers/ahokvs-anies-the-showdown/

5. "Ahok vs Anies: The Showdown" And

6. "Governor Ahok concedes Jakarta election to Baswedan"

Source from http://www.aljazeera.com/news/2017/04/gove rnor-ahok-concedes-jakarta-electionbaswedan-170419174009760.html.

Diction or choice of words used in the headlines above are truly wise, because here those who compete in the governor's election are only between individuals, between Ahok and Anies, not competition between religions.

Mass media in Indonesia should have been a conditioning remedy with the news by using 'harmonious' language and choice of words, so that they can maintain sympathy, empathy, and broaden the horizons and deepen people's understanding in addressing events wisely through the news they read. Certainly, a good and wise headline should be followed and accompanied by wise news content as well.

7. 'Ahok' Case Highlights Indonesia's Blasphemy Law | Voice of America (https://www.voanews.com/ eastasia-pacific/ahok-case-highlightindonesias-blasphemy-law) Ahok, an ethnic Chinese Christian in a Muslim-majority nation, was found guilty of blasphemy by the North Jakarta District Court, May 9, 2017,

Meiliana, a 44-year-old ethnic Chinese Buddhist, sMeiliana, a 44-year-old ethnic Chinese Buddhist, sits in a courtroom for blasphemy charges, in Medan, Sumatra, Indonesia, Aug. 21, 2018.

Among those minorities, other than Ahok, the person who has attracted the most attention is Meiliana, a 44-year-old Chinese Buddhist, who was found guilty of insulting Islam after asking her neighborhood mosque in 2016 to lower the volume of its sound system used in the call to prayer. She said it hurt her ears.

The headline above completely used a wise diction since there is no any single word is made to confront to each other. It has straightly used the person or the perpetrator of the blasphemy. In other way the headline would say that "Ahok" was the perpetrator of the blasphemy against some religion in this case is Islam, and it surely had nothing to do with his religious belief.

Unfortunately, that the lead and some paragraphs were by no means have wise dictions. It showed us by the use of religious words 'Christian' and 'Muslim' and 'Buddhist. There is nothing significant by confronting those three words if it is aimed to purely presenting, rather than purposely would arouse a conflict among the respective followers of the religions.

Anoher thing is the use of ethincal diction 'chinese' here seemed to emphasize minority against the majority of Indonesia citizens.

8. Jakarta frees former Christian governor convicted of blasphemy

(http:/www.asianews.it/news-en/jakatafrees-former-Christian-governor-convictedof-blasphemy-46058.html)

Jakarta (AsiaNews) - Former governor of Jakarta, Chinese ethnic Christian Basuki "Ahok" Tjahaja Purnama, is free again after serving almost two years for blasphemy...

This headline, even though it doesn't have and make two dictions collide to one other, but still it is not necessary to use dictions 'Christian' before the word 'governor'. This along 
with ethnic diction 'Chinese' should also be removed out of the headline to decrease a negative impact resulted in religious and ethnical sensitivity.

This could be better emphasizing only on the word 'former', without having to use diction which would hurt someone, party, or any religious groups.

The alternative could be: "Jakarta frees former governor of Jakarta convicted of blasphemy."

9. Indonesian Christian politician held on blasphemy charges released from jail (https://www.google.com/amp/s/beta.washin gtonpost.com/world/asia_pacific/)

JAKARTA, Indonesia - Former Jakarta governor Basuki Tjahaja Purnama, better known by his nickname Ahok, was released from prison Thursday morning after serving almost two years on charges of blasphemy against Islam.

The conviction and detention of an ethnic Chinese Christian governor after a popular campaign against him was widely seen as a sign of the growing power of political Islam in Muslim-majority Indonesia, which has positioned itself as a moderate, secular and pluralist country.

Both this headline and the lead as well as one of the paragraph used religious and ethnical diction. Here the title eventhough there is no single diction banged one another, while in the second paragraph above the words 'Chinese', 'Christian' are being clashed

On the other way aroung the first paragraph of this headline is completely wise in using diction to convey the massage, that no sensitive dictions are fractioned here. The lines run wisely by directly pointing the perpetrator without having to add any religious or ethnical diction which tend to result in negative effect in society.
10. Christian Governor in Indonesia Found Guilty of Blasphemy Against Islam (https://www.google.com/amp/s/www.n ytimes.com/2017/05/09/asia/amp.html/)

This headline perfectly provoke a insecured condition in society by clearly using two religious dictions 'Islam' and 'Christian', and make them clash to one another. It is purposely made as if that the real fight on blasphemy is between Islam and Christian, while actualy that 'somebody' in this case is the governor of Jakarta is the perpetrator. Indirectly as if it would say that Christians here represented by a governor have conflict with Islam. There was no way it was true, the truth is the perpetrator who does, the his religious belief.

11. Christian governor of Jakarta found guilty of blasphemy for saying Muslims should vote for him

(https://www.google.com/amp/s/www.i ndependent.co.uk/news/world/asia/)

Basically there is nothing wrong when somebody who ran for a governor to ask support from a group or organization to succeed the election; however, by putting religious dictions here can give a rise a sensitivity fanaticism from both sides of the religions. This kind of diction should have been avoided to minimize controversy of a kind to keep conducive condtion in society.

12. Christian governor loses Jakarta run-off in religiously tense polls

(https://www.google.com/amp/s/amp.rap pler.com/world/regions/asia-

pacific/indonesia/bahasa/englishedition/ 167380/)

JAKARTA, Indonesia - Jakarta's Christian governor on Wednesday, April 19, lost heavily to a Muslim former government minister in an election run-off, private polls indicated, after a divisive battle that has damaged Indonesia's reputation as a bastion of tolerant Islam. 
The lead of this headline clearly and straightly seemed to crash the followers of the two religions. It is completely unhealthy headline, for it would probably cause a jealousy of one side in a society.

13. Jakarta election: Christian governor concedes to Muslim rival

(https://www.google.com/amp/s/www.bbc. com/news/amp/world-asia-39636974)

Jakarta's first Christian governor has conceded defeat to a Muslim former government minister in a vote seen as a test of Indonesia's secular identity.

Basuki Tjahaja Purnama congratulated his rival after exit polls showed Anies Rasyid Baswedan clearly ahead.

This headline and the lead inside contained provoking by using religious dictions. It shows as if that the two religions are competing, in this case are Islam and Christian, while actually the candidates who ran for governor who are competing, it doesn't have anything to do with their religious beliefs.

However the lines of the next paragraph below the headline says wisely in breaking the news by only saying the names of the competing candidates who ran for the governor.

14. Christian couple caned in Banda Aceh for gambling

(https://www.google.com/amp/s/www.th ejakartapost.com/amp/news/2018/02/27/ html)

The Aceh Sharia Court sentenced the Christian couple, identified as Dahlan Sili Tongga, 61, and Tjia Nyuk Hwa, 45, to eight and seven lashes respectively for violating provincial laws.

We know that Aceh Province is one of the provinces in ndonesia that has exclusive administration in which Syari'ah Law prevails and is applied there. It means the law in Aceh is based on the Islamic teaching. But it doesn't mean when making a headline, somebody's religious belief is to be mentioned anyway, or else it has a secret agenda or propaganda to provoke and creat insecurity in society not making headline itself.

In this case, the religion of the perpetrator is removed. It is not necessary to add religious diction 'Christian' before the word 'couple' in the title.

The headline would be good if it says like the alternative below "Couple caned in Banda Aceh for gambling"

15. Indonesian Christian whipped for selling alcohol in Aceh

(https://www.google.com/amp/s/www.ns t.com.my/node/326939/amp)

BANDA ACEH: An Indonesian Christian was publicly flogged on Friday for selling alcohol in conservative Aceh province, a violation of Islamic law, as a crowd of onlookers including children jeered.

Again this headline uses religious dictions, it seems to emphasize that it is primarily because of the perpetrator's religion so that made him convicted in the province that uses Islamic law, not only because of the wrongdoing of perpetrators who have violated the Sariah law by selling alcohol. This headline implicitly shows the readers as if it is the religion he believes that has become the more burdensome factor for him in this case.

16. Christian couple sentenced to flogging for gambling in Aceh

(http://www.asianews.it/news-

en/43223.html)

Dahlan Sili Tongga, 61, and Tjia Nyuk Hwa, 45, were convicted for breaking Islamic law. Aceh is the only territory in Indonesia to enforce Sharia. The couple chose corporal punishment over prison. Each lash is the equivalent to a month in prison.

This headine and the lead are contradicted to each other. The headline still uses the word 'Christian' that might 
give rise to religious sensitivity and create unconducive situation in society, meanwhile the following paragraph wisely in telling the news by not adding any religious dictions. It contains only the perpetrators who broke the Islamic Law in the province.

17. Buntut Pidato Provokatif, Gubernur Kalbar Diusir dari Aceh dan Ditolak di Sejumlah Daerah

(https://www.tarbiyah.net/2017/05/html $? m=1)$

Akibat pidatonya yang provokatif dan dinilai intoleran terhadap Islam, Cornelis mulai kena batunya. Gubernur Kalimantan Barat itu diusir dari Aceh dan ditolak di sejumlah daerah.

This includes good and thoughtful headlines in the selection of the dictions. It doesn't use sensitive diction related to religion or ethnicity. it is clear that solely a governor from West Kalimantan who has a problem,even though he is a Christian, but his religious belief is not added to the title so as not to trigger further religious conflict.

18. Another Ahok? Chinese Christian faces blasphemy rap in Muslim Indonesia (https://www.google.com/amp/s/amp.sca mp.com/week-

asia/politics/article/2175671/)

But on November 22, 11 days after the ethnic Chinese Protestant addressed members of her Indonesian Solidarity Party (PSI) and their guest, President Joko Widodo, she was summoned for seven hours of questioning.

The headline above used two religious names; Christian dan Muslim. These words clearly made to contradict to each other. This could impact, and even raise conflict among their respective followers. We exactly know that during this period of recent government religious issues is made to 'disrupt our nation's national security and community's stabilization.
Beside using the word 'Protestant', the other unwise choice found here is the use of ethnical diction 'chinese'. This diction shouldn't have been used since it could impress negatively and amphasize the minority of Chinese citizen of Indonesia against the majority, and again it was purposely made to them collide to each other.

19. PPMI Reports PSI Chair Grace Natalie to Police (https://en.tempo.co/read/923521/ppmi)

TEMPO.CO, Jakarta - The chairwoman of the Indonesian Solidarity Party, Grace Natalie, has been reported to the National Police's criminal investigation division (Bareskrim) for alleged blasphemy related to her recent statement against the creation of a religion-based regional regulation (Perda).

Grace was reported to the police by the Indonesian Muslim Workers' Brotherhood (PPMI) as the latter deemed her statement contained elements defying the Holy Quran.

This is another a good and wise headline with the lead inside. It emphasizes only on the perpetrator of the blasphemy, and on the position she has namely as the chairwoman of PSI. Although we know that the key issue is related to religious domain but it doesn't mention her religious belief to make the headline and interesting to read.

20. Grace Natalie Dilaporkan ke Bareskrim Polri terkait Penistaan Agama

(https://www.google.com/amp/s/am p.kompas.com/nasional/read/2018/1 1/16/18284441/)

JAKARTA, KOMPAS.com - Sekretaris Jenderal Persaudaraan Pekerja Muslim Indonesia (PPMI) Zulkhair melaporkan Ketua Umum Partai Solidaritas Indonesia (PSI) ke Bareskrim Polri, Jakarta Pusat, Jumat (16/11/2018). Grace dilaporkan atas dugaan tindak pidana penistaan agama.

This is also one of good and wise headlines, for it only emphasizes on the 
perpetrator who did alleged blasphemy. It doesn't put any religious sensitive diction to make this headline interesting. It focuses merely on the perpetrator's position as the chairwoman of an organization PSI not her religious belief and ethnicity.

\section{CONCLUSIONS}

Religious dictions are basically a kind of positive dictions for it covers actually all the good things contained the some religion's teachings, however; it could turn into something negative and result in bad impact when used in improper ways, for the sake of hidden agenda to disrupt caused unconducive condition in society for political interests

Religious dictions is better not used outside the context of a particular religion or belief to avoid things that might happen as mentioned above. Likewise with the dictions which related to ethnicity.Indonesia is a country that is formed or in other words it is built from various ethnicities so that the use of dictions related to ethnicity should remain in the corridor or still in the context of a particular ethnicity. Avoid words or sentences that mean a comparison or to clash two or more ethnic groups so as to prevent misunderstandings among them.

\section{Bibliography}

Ambo, A. E. (1988). Dasar-dasar Keterampilan menulis . Jakarta: Departemen Pendidikan dan Kebudayaan.

Assegaf, H. D. (1991). Jurnalistik masa kini. Jakarta: Ghalia Indonesia.

Indrawati, N. (2018). Bahasa persuasif kaum milenial pada pilpres 2019. UNDAS: Jurnal Hasil Penelitian Bahasa Dan Sastra, 14(2), 159-170.
Retrieved from http:/ /ojs.badanbahasa.kemdikbud .go.id/jurnal/index.php/undas/art icle/view/1148

Indrawati, N. (2019). Analisis elaboration Likelihood model dalam kalimat persuasi kampanye Presiden 2019 di facebook. UNDAS: Jurnal Hasil Penelitian Bahasa Dan Sastra, 15(2), 175.

https://doi.org/10.26499/und.v15i 2.1741

Itule, B., \& Anderson, D. (2003). A news writing and reporting. Beijing: China People's University Press.

Kaelan. (2012). Metode penelitian kualitatif interdisipliner. Yogyakarta: Paradigma.

Keraf, G. (1996). Tata bahasa Indonesia. Cetakan kesepuluh. Jakarta: Ikrar Mandiri Abadi.

Keraf, G. (2008). Diksi dan gaya bahasa komposisi lanjutan. Jakarta: Gramedia Pustaka Utama.

Lusita. (2018). Analisis diksi, bahasa figuratif, dan citraan serta nilai pendidikan karakter dalam kumpulan cerpen Perempuan Yang Disunting Gelombang Karya Indra Tranggono. 1(1). Retrieved from http://www.academia.edu/downl oad/59334671/Lusita_20190520115691-bv11rc.pdf

Milles, M. B., \& Huberman, A. M. (1992). Analisis data kualitatif. (Terjemahan Tjetjep Rohendi). Jakarta: University Indonesia Press.

Mustakim. (1994). Membina kemampuan berbahasa. Jakarta: PT Gramedia Pustaka Utama.

Widyamartaya, A. (1990). Seni Menuangkan Gagasan. Yogyakarta: Penerbit Kanisius. 